\author{
ks. st. kpt. Adam Glajcar
}

\title{
Kilka słów o rozmowie duszpasterskiej
}

\author{
Pastoral Conversation - A Brief Outline
}

Несколько слов о пастырской беседе

\begin{abstract}
ABSTRAKT
Cel: W straży pożarnej służą kapelani. W artykule zwrócono uwagę na bardzo ważną część ich służby w tych strukturach - na rozmowę duszpasterską. Służba kapelańska opiera się przede wszystkim na komunikacji z drugim człowiekiem. Strażak-ratownik potrzebuje rozmowy, potrzebuje wsparcia - także duszpasterskiego. Jednak prowadzenie rozmowy duszpasterskiej wymaga od duchownego przygotowania, wiedzy i doświadczenia. Właśnie na te elementy położono nacisk w artykule.

Wprowadzenie: Nie ma dziś służb mundurowych, w których nie służyliby kapelani. Czy są oni potrzebni w straży pożarnej? Na to pytanie można odpowiedzieć słowami, które kiedyś wypowiedział Komendant Główny Państwowej Straży Pożarnej: „Przed psychologiem, nawet najlepszym interwentem od traumy, strażacy nie powiedzą, że im się nie układa, że dziecko wpadło w złe towarzystwo, że matka umiera na raka, że sięgają zbyt często po kieliszek, że... Można by wyliczać bez końca. Otwierają się przed strażakiem - kapelanem” [25, s. 16]. Trzeba być jednak świadomym tego, że służba kapelańska polega nie tylko na tym, żeby strażak, poszkodowany dotarł do kapelana, ale także na tym, żeby to kapelan dotarł do potrzebującego. Kiedy jest to konieczne, kapelan bierze w ręce sprzęt pożarniczy, ale najczęściej posługuje się mową. Prowadzenie samej rozmowy wydaje się bardzo proste, ale tak nie jest, bo każdy rozmówca jest inną osobą. W niniejszym artykule zwrócono uwagę na to, że duszpasterz jest przede wszystkim słuchaczem, który umie poświęcić czas współrozmówcy. Nawiązanie właściwego kontaktu z kimś, kogo się zna, jest proste. O wiele trudniej nawiązać go z osobą, którą widzi się pierwszy raz. Na przebieg rozmowy ma wpływ wiele czynników - zewnętrznych i wewnętrznych. Trzeba pamiętać, że duszpasterz nie jest jedyną osobą pomagającą swojemu rozmówcy. W tym zakresie powinien on współpracować z psychologami i lekarzami. Tylko wtedy rozmowa czy porada duszpasterska będą satysfakcjonujące dla obu stron

Wnioski: Duszpasterz służący w straży pożarnej nie może kierować się wyłącznie przesłankami konfesyjnymi. Do każdej rozmowy musi być przygotowany, co wymaga ciągłego samokształcenia. Duszpasterz powinien szukać rozmówcy, a nie na niego czekać. Rozmowa nie jest monologiem prowadzonym przez kapelana, lecz prawdziwym dialogiem. Podczas rozmowy kapelan pomaga potrzebującemu znaleźć właściwe rozwiązanie problemu, jednak w tym procesie powinien poruszać się tylko w przestrzeni zaproponowanej przez rozmówcę.
\end{abstract}

Słowa kluczowe: duszpasterz, rozmowa duszpasterska, pomoc

Typ artykułu: z praktyki dla praktyki

Przyjęty: 30.10.2017; Zrecenzowany: 06.12.2017; Opublikowany: 29.12.2017;

Proszę cytować: BiTP Vol. 48 Issue 4, 2017, pp. 88-95, doi: 10.12845/bitp.48.4.2017.6;

Artykuł udostępniany na licencji CC BY-NC-SA 4.0 (https://creativecommons.org/licenses/by-nc-sa/4.0/).

\section{ABSTRACT}

Aim: Pastors serve in the fire service. This paper focuses on a very important aspect of their duties - the pastoral conversation. A chaplain's service primarily involves communicating with other people. A fire-fighter-rescuer needs support and someone to talk to - including a pastor. However, holding a pastoral conversation requires a priest/pastor to be spiritually prepared, knowledgeable and experienced. These three aspects are emphasised in this paper. Introduction: Nowadays, chaplains serve in all uniformed services. Are they really necessary in the fire service? A perfect answer to this question can be found in the words of the Chief Fire Officer of the State Fire Service: „A fireman will never come to a psychologist, even if he is a top professional who can perfectly handle traumatic experiences, to talk about his personal issues: that things are not fine, that his child is keeping bad company, that his mother is dying of cancer, that he hits the bottle, that... The list goes on and on. The only person a fireman will open up to is a fireman-chaplain" [25, p. 16]. We have to be aware, however, that a chaplain's service involves not only responding to traumatised fire-fighters who are asking for help, but also reaching out to those who have not yet asked for it. When necessary, the chaplain will fight the fire, but his primary role is to listen and talk. Holding a conversation is not as easy as it may seem, since each person confiding in the chaplain is a different person. This paper highlights the role of a chaplain as being primarily that of a confidant who can devote his time to listen what firefighters have to say. Establishing a rapport with someone we know is always relatively easy. It is much more difficult, however, to establish it with a person we do not know and perhaps see for the first time. Many external and internal factors come into play. It has to be underlined that the pastor in not the only person who provides help. He should cooperate with psychologists and doctors. Only then can a pastoral conversation or advice be regarded as satisfactory for both sides. 
Conclusions: Pastors who serve in the fire service should not be guided by religious considerations only. They must be prepared for every conversation and this requires continuous self-education. Pastors should reach out to those who need to talk instead of waiting for them. A pastoral conversation is not a monologue by a chaplain, but an actual dialogue. During this dialogue, the chaplain is trying to help the person in need to find the right solution to the problem. In doing so, however, he must not cross the line drawn by the person who confides in him.

Keywords: pastor, pastoral conversation, help

Type of article: best practice in action

Received: 30.10.2017; Reviewed: 06.12.2017; Published: 29.12.2017;

Please cite as: BiTP Vol. 48 Issue 4, 2017, pp. 88-95, doi: 10.12845/bitp.48.4.2017.6;

This is an open access article under the CC BY-NC-SA 4.0 license (https://creativecommons.org/licenses/by-nc-sa/4.0/).

\section{АННОТАЦИЯ}

Цель: В пожарной охране служат капелланы. В статье обращается внимание на очень важную часть их службы в этих структурах - пастырскую беседу. Служба капелланов основана в главном на общении с другим человеком. Пожарный-спасатель нуждается в разговоре, ему нужна поддержка - также и со стороны священника. Однако проведение пастырской беседы требует от священника подготовки, знаний и опыта. Основное внимание в статье уделяется именно этим элементам.

Введение: Сегодня нет унифицированных служб, в которых не служили бы священники. Нужны ли они в пожарной службе? На этот вопрос можно ответить словами главнокомандующего Государственной пожарной службы: „Психологу, даже лучшему специалисту по травмам, пожарные не скажут, что им плохо, что ребенок попал в плохую компанию, что мать умирает от рака, что они слишком часто пьют, что .. Можно перечислять без конца. Они открываются перед пожарным - капелланом" [25, с. 16]. Однако следует помнить, что служба капеллана состоит не только в том, чтобы пожарный, пострадавший пришел к капеллану, но также в том, чтобы капеллан прибыл к пострадавшему. Когда необходимо, капеллан берет в руки пожарное оборудование, но чаще всего пользуется речью. Проведение беседы кажется очень простым, но это не так, потому что каждый собеседник - другой человек. В этой статье обращено внимание, что священник - это прежде всего слушатель, который знает как посвятить время своему собеседнику. Установить соответствующий контакт с кем-то знакомым легко. Намного сложнее установить его с человеком, которого видишь первый раз. Многие факторы - внешние и внутренние - влияют на ход разговора. Следует помнить, что священник - не единственный человек, который помогает своему собеседнику. В этой сфере он должен сотрудничать с психологами и врачами. Только тогда беседа со священником или его советы будут удовлетворительными для обеих сторон. Выводы: Священник, котрый служит в пожарной охране, не может руководствоваться только религиозными убеждениями. К каждому разговору он должен быть подготовлен, соответсвеннно это требут от него постоянного саморазвития. Священник должен искать собеседника, а не ждать его. Разговор - это не монолог капеллана, а реальный диалог. Во время беседы капеллан помогает нуждающимся найти соответствующее решение проблемы, но в этом процессе он должен перемещаться только в пространстве, предложенном собеседником. Ключевые слова: пастырь, пастырская беседа, помощь

Вид статьи: с практики для практики

Принята: 30.10.2017; Рецензирована: 06.12.2017; Опубликована: 29.12.2017;

Просим ссылаться на статью следующим образом: BiTP Vol. 48 Issue 4, 2017, pp. 88-95, doi: 10.12845/bitp.48.4.2017.6;

Настоящая статья находится в открытом доступе и распространяется в соответствии с лицензией CC BY-NC-SA 4.0 (https://creativecommons.org/ licenses/by-nc-sa/4.0/).

\section{Wprowadzenie}

Z duszpasterzami spotykamy się nie tylko w świątyni. Uczestniczą oni w życiu społecznym, zawodowym i rodzinnym. Gdyby ich działalność była widoczna tylko w życiu liturgicznym, nie moglibyśmy mówić o prawdziwym duszpasterstwie. Dziś prawie wszystkie szpitale mają swoich kapelanów. Mają ich też służby mundurowe, w tym Państwowa Straż Pożarna. Strażacka służba jest bardzo trudna, odpowiedzialna, stresogenna, przez co wymaga nie lada poświęcenia i hartu ducha. Jest to ratownictwo w pełnym tego słowa znaczeniu. Cechą tej służby jest codzienne ocieranie się o ludzką niedolę, krzywdę, tragedię, a nawet śmierć. Śmierć dotyka nie tylko poszkodowanych, lecz także osób niosących pomoc, strażaków [10, s. 185]. To rodzi wiele pytań i wątpliwości, może być też powodem załamania psychicznego. Trudne pytania są nie tylko natury egzystencjalnej; dotyczą też sfery psychiki, funkcjonowania rodziny, spraw wiary, w tym kwestii istnienia Boga itp. [9, s. 208-209] Właśnie w takich chwilach potrzebna jest obecność duszpasterza niosącego pomoc poszkodowanemu. Ta pomoc odbywa się na zasadzie dialogu. Celem duszpasterskiej rozmowy jest wspólne szukanie prawdy i dążenie do jej wypowiedzenia. W takiej rozmowie dba się o właściwe słuchanie i właściwą odpowiedź człowieka, tworu Bożego, na zadanie powierzone mu przez Stwórcę i Ojca, odpowiedź na to, co "nas bezwarunkowo obchodzi". Zasadą rozmowy duszpasterskiej musi więc być - wspomniana już - prawda, a także miłość [23, s. 14]. Wynika z tego, że duszpasterska pomoc kieruje się "do serca" człowieka. Tak naprawdę chodzi tu o stosunek człowieka do Boga. Idąc za Ojcem Reformacji, ks. dr. Marcinem Lutrem, należy powiedzieć: tu chodzi o wiarę. Wiara prześwietla najskrytsze zakamarki ludzkiego życia. „Dlatego rozmowa duszpasterska nie może się kierować jedynie do rozumu, jak rozmowa naukowa, nie tylko do potrzeb towarzyskich człowieka, jako rozrywka i odprężenie, niczym pogawędka, ale ma na oku wszelkie jego zdolności i dążenia, bierze jego Boskie przeznaczenie na serio i korzysta przeto z wszelkich rodzajów rozmowy" [13, s. 38]. 


\section{Przygotowanie - początek relacji}

Mówiąc o pomocy duszpasterskiej, można pokusić się o pewne analogie do strażackich działań. Każda akcja ma swój początek, po którym podejmowane są czynności zmierzające do rozpoznania, zlokalizowania i w końcu zlikwidowania pożaru czy zagrożenia. Skuteczność akcji zależy od dobrego przygotowania strażaków, rozpoznania zagrożenia oraz zadysponowania odpowiednimi siłami i środkami. Wydaje się, że nie inaczej jest z pomocą poszkodowanemu. Duszpasterz może mieć pewne wątpliwości dotyczące tego, od czego rozpocząć rozmowę z osobą, której nie zna, a zwłaszcza z osobą, której chrześcijaństwo jest obce lub obojętne. Na pewno kardynalnym błędem byłoby zapytanie o światopogląd albo podjęcie kwestii obojętności wobec Boga czy nieuczestniczenia w życiu religijnym, kościelnym. Rozmowę należy zacząć od tematu, który będzie interesował współrozmówcę. To ma być najzwyklejsza pogawędka. Osoba niosąca duszpasterską pomoc musi być świadoma tego, że chęć zwiastowania Ewangelii i nawrócenia poszkodowanego za wszelką cenę należy zostawić w domu. Zwiastowanie jednak powinno być widoczne, zaznaczone w rozmowie - poprzez wytworzoną atmosferę, poprzez zachowanie duszpasterza. Kiedy należy je zwerbalizować? 0 tym decyduje duszpasterz, bo każda rozmowa jest inna. Wszystko zależy od osoby potrzebującej, od jej nastawienia do duszpasterza, do sytuacji, w której się znalazła, i do problemu, który ją trapi. Może się okazać, że pomoc duszpasterska będzie polegała nie tylko na jednej rozmowie, ale na cyklu rozmów, a wtedy zwiastowanie nie nastąpi podczas pierwszego spotkania, lecz podczas drugiego. To już na pewno nie będzie zwykła pogawędka czy wymiana doświadczeń między partnerami, ale coś znacznie więcej.

Bardzo istotną sprawą jest odpowiednie przygotowanie gruntu do rozmowy. Chodzi tu o przygotowanie zewnętrzne, które może mieć wielki wpływ na jej przebieg. Rozmowa może odbywać się w różnych miejscach, np. w: kancelarii parafialnej, jakimś pokoju, pomieszczeniu na terenie jednostki straży pożarnej, kawiarence, domu współrozmówcy czy na ławce w parku. Niejednokrotnie jest to sala szpitalna albo sanatoryjna. Najlepszym miejscem jest łono natury, gdzie zewnętrzne przeszkody, jak ludzie czy ruch kołowy i pieszy, nie przeszkadzają w rozmowie. Wówczas łatwiej skupić się na słuchaniu, prowadzeniu dialogu czy medytowaniu. Gdy nie ma możliwości wyjścia na zewnątrz i konieczne jest pozostawanie w budynku, trzeba wybrać takie miejsce, które nie stwarza niepotrzebnych barier i nie zdradza zamiłowań duszpasterza do techniki, muzyki i innych rzeczy, tak by współrozmówca nie był rozpraszany czynnikami zewnętrznymi. Jeśli rozmowa odbywa się wieczorem, to lampę należy ustawić tak, by nie oślepiała osoby potrzebującej. Mogłoby się wydawać, że są to sprawy błahe, ale według psychologów mają one niebagatelny wpływ na początek i przebieg rozmowy. Nie inaczej jest z pozycją duszpasterza i jego współrozmówcy. To ma być pozycja koinonii, wspólnoty, solidarności oraz otwartości dla i na siebie [2, s. 49].

W kontekście zewnętrznego przygotowania do rozmowy trzeba wspomnieć o jeszcze jednej bardzo istotnej kwestii. Otóż człowiek poszukujący pomocy duszpasterskiej powinien być zrelaksowany, odprężony. Pomocne w tym może być wygodne siedzenie. Duszpasterz nie może siedzieć wyżej niż jego współrozmówca, nie może też siedzieć na luksusowym krześle czy fotelu, a poszkodowanego sadzać na zwykłym krześle, bo wtedy rozmowa będzie dużo trudniejsza albo nie będzie jej wcale. Spotkanie można rozpocząć od poczęstowania współrozmówcy kawą, herbatą, wodą czy sokiem. Duszpasterz powinien zadbać o to, by w czasie rozmowy mieć wyłączony telefon, i o to, by nikt z zewnątrz nie zakłócał spotkania. Jest bardzo prawdopodobne, że wówczas współrozmówca będzie miał komfort i pewność, że duszpasterz naprawdę chce mu poświęcić czas i pomóc w rozwiązaniu problemu.

Sytuacja każdego poszkodowanego jest inna. Każdy zaczyna swoją rozmowę inaczej. To obliguje duszpasterza do bardzo uważnego słuchania.[19, s. 35] Trzeba pamiętać, że zazwyczaj na początku rozmowy osoba szukająca pomocy przedstawia tylko wąski wycinek problemu dotyczący rodziny, pracy, służby. Często jest wtedy podekscytowana, zaniepokojona. Być może formułuje swoją wypowiedź nieskładnie, ale na pewno jest w tej wypowiedzi bardzo uczciwa. Wówczas duszpasterzowi o wiele łatwiej jest nawiązać kontakt i kontynuować rozmowę. Czasami jednak trudno go nawiązać. Zdarza się, że duszpasterz odczuwa, że współrozmówca ukrywa to wszystko, co mu przeszkadza, że nie chce jasno i szczerze powiedzieć o swoich problemach. Taka osoba najczęściej opowiada jakieś historie ze swego życia, które nic nie wnoszą do rozmowy, nie mówią o istocie sprawy, o powodzie spotkania z duszpasterzem. Co wtedy ma zrobić duchowny? Jak ma próbować pomóc poszkodowanemu? Najlepiej będzie, jak pozwoli mu się wypowiedzieć. Współrozmówcy trzeba bardzo uważnie słuchać. Słuchanie jest sztuką. W Starym Testamencie czytamy: „Pilnuj swoich kroków, gdy idziesz do domu Bożego, i nastaw się na słuchanie, gdyż jest to lepsze niż ofiary składane przez głupich..." (Kazn. 4,17), a także: „I oczy tych, którzy widzą, nie będą oślepione, i uszy tych, którzy słyszą, będą uważnie słuchać" (Iz 32,3). Z tych wersetów oraz z różnych badań wynika, że podstawową cechą dobrego słuchacza jest cierpliwość i uwaga, jaką poświęca się mówiącemu. Zarówno cierpliwość, jak i uwaga rzadko mają takie samo natężenie w dłuższym czasie. Bardzo ważnym elementem jest tu kontakt wzrokowy ze współrozmówcą. Tylko w ten sposób można zdobyć jego zaufanie i zbliżyć się do niego.

Największy problem podczas udzielania pomocy duszpasterskiej pojawia się wtedy, gdy poszkodowany nie rozpoczyna rozmowy. Wówczas ten obowiązek spada na duszpasterza. Zdarza się, że duszpasterz pierwszy raz widzi osobę poszkodowaną, nie zna jej zainteresowań ani zawodu. Może wtedy powiedzieć kilka słów o pogodzie. Jeśli duszpasterz wie, czym zawodowo zajmuje się poszkodowany, może rozpocząć rozmowę od spraw zawodowych, a następnie przejść do ogólnoludzkich bolączek, do tego, co dziś interesuje człowieka. To pozwoli współrozmówcy nabrać pewności siebie, poczuć się równorzędnym partnerem w rozmowie. Wówczas duszpasterzowi łatwiej będzie skierować rozmowę na właściwe tory i przejść do istoty sprawy. Jednakże duszpasterz musi cały czas pamiętać, że niczego nie wolno przyspieszać ani wymuszać, że nikogo nie można zmuszać do zwierzeń. Duszpasterz musi tak kierować rozmową, aby powoli przechodzić od spraw ogólnych do najważniejszych. To na pewno pomoże mu w zdobyciu zaufania 
współrozmówcy, dzięki czemu zostanie nawiązany właściwy kontakt. Nawiązanie kontaktu to pierwszy etap rozmowy, pomocy duszpasterskiej. Na tym etapie nie można dowiedzieć się wszystkiego.[11, s. 20] Nie można zatem stawiać diagnozy, bo to mogłoby doprowadzić do fałszywych wniosków.

\section{Poszukiwanie diagnozy}

Postawienie diagnozy w kolejnej fazie rozmowy duszpasterskiej nie załatwia wszystkiego. Duszpasterz nie może zrezygnować z dalszego poznawania psychiki swego współrozmówcy. To byłby wielki błąd. Słowo "diagnoza" pochodzi z języka greckiego (diagnosis) i oznacza rozpoznanie choroby na podstawie jej objawów. Z tym terminem spotykamy się najczęściej w medycynie. To na podstawie diagnozy podejmuje się stosowne leczenie. Jednakże diagnozowanie nie jest zarezerwowane tylko dla medycyny. Dziś diagnozuje się nastroje społeczne, stan rzeczy, a nawet działanie PSP. Dlaczego tak się dzieje? Wydaje się, że diagnoza kojarzy się z czymś bardzo precyzyjnym, przemyślanym, uwzględniającym wszystkie próby najdokładniejszego określenia i zbadania tego, o czym się orzeka.

Duszpasterz podejmujący się pomocy poszkodowanemu nie jest lekarzem ani psychologiem praktykiem i stawiana przez niego diagnoza nie jest równoważna z diagnozą lekarską czy psychologiczną. Jednakże niezbędną czynnością, którą duszpasterz musi wykonać w początkowej fazie rozmowy, jest określenie problemu będącego przedmiotem tej rozmowy. W tym celu duszpasterzowi potrzebna jest pewna wiedza na temat psychopatologii oraz znajomość kilku zasad psychologii. Duszpasterz musi być bardzo pokornym wobec słuchacza, ale także wobec siebie i swojej wiedzy [1, s. 34].

Duszpasterz zajmujący się poradnictwem, pomocą poszkodowanemu musi przede wszystkim odpowiedzieć sobie na pytanie, czego dotyczy problem osoby, z którą rozmawia. Jego podstawowym zadaniem jest sformułowanie, sklasyfikowanie informacji przedstawionych mu przez tę osobą. Następnie duszpasterz musi się zastanowić, co zamierza robić w zaistniałej sytuacji. To musi być działanie świadome, przemyślane i w znacznym stopniu zaplanowane. Etap formułowania jakiegokolwiek wniosku jest bliski stawianiu wstępnej diagnozy. Diagnozowanie powinno charakteryzować się dwoma stylami (sposobami) myślenia. Duszpasterz, który się tego podejmuje, musi myśleć w sposób uporządkowany, systematyczny, ale jednocześnie elastyczny i dynamiczny [21, s. 76]. Na tym etapie powinien on odpowiedzieć sobie na następujące pytania [2, s. 93]:

- Jaki problem ma osoba szukająca pomocy? Co ją trapi? $\mathrm{Na}$ co się skarży? Z czym nie daje sobie rady? Co najbardziej jej dokucza? Jakie są objawy, zaburzenia zachowania i na co się skarży, z czym sobie w ogóle nie radzi i co jej najbardziej przeszkadza?

- Co spowodowało lub powoduje problem? Jakie czynniki czy zdarzenia doprowadziły do występowania danych objawów czy zaburzeń zachowania?

- Czego brakuje? (W tym pytaniu chodzi o to, czego osoba szukająca pomocy nie robi, o czym nie mówi, czego nie czuje i o czym nie myśli).
- Co jest potrzebne w tej sytuacji? Co należy zrobić, żeby ustąpiły lub zmniejszyły się objawy czy zaburzenia zachowania? Jakie działania należy podjąć, a z jakich zrezygnować? Jakie działania mogą przynieść oczekiwane efekty w krótkim czasie, a jakie spowodują zmiany w dłuższym okresie?

Odpowiedzi na te pytania należy czerpać przede wszystkim od poszkodowanego, ale nie można zapominać o innych źródłach: lekarzach, rodzinie, współpracownikach. Jednakże trzeba też pamiętać, że oprócz diagnozy problemu bardzo ważna jest diagnoza sposobu, w jaki poszkodowany prosi o pomoc. Będzie to diagnoza motywacji do zaangażowania się w uzyskanie pomocy. Tylko od poszkodowanego zależy, ile czasu poświęci na rozmowę. To jest jego osobista decyzja. Wielu poszkodowanych oczekuje od lekarzy, a może nawet od psychologów, spektakularnych, błyskawicznych efektów pomocy, a więc prosi o szybkie rozwiązanie problemów. W takich przypadkach duszpasterze muszą bardzo uważać. Duchowny nie ma należytego oglądu sytuacji i może całkiem nieświadomie podtrzymać nierealistyczne oczekiwania poszkodowanego co do ostatecznego efektu rozmowy czy pomocy duszpasterskiej. To może doprowadzić do wielkich napięć i konfliktów w relacji między duchownym a osobą, która potrzebuje pomocy, porady czy rozmowy. Wynika z tego jasno, że w czasie spotkania duszpasterz powinien postawić jakby trzy diagnozy cząstkowe: diagnozę problemu, diagnozę motywacji i diagnozę teologiczną. W diagnozie teologicznej chodzi o to, by spojrzeć na współrozmówcę z punktu widzenia Boga, by zobaczyć, jak Bóg prowadził go przez życie i jak on odbiera, przeżywa Boże prowadzenie, Bożą obecność w swoim życiu. Ksiądz prof. Jerzy Gryniakow (za Adelheidem Renschem) radzi, by formułując diagnozę teologiczną, duszpasterz stawiał następujące pytania:

- „Jak bardzo w tym człowieku jest obecna prawdziwa, żywa wiara (na poziomie świadomym i nieświadomym)?

- Jakie zadatki prawdziwej wiary, jej mocy i intencji, posiada ten człowiek, tak, iż można mieć nadzieje na ich rozwiązanie?

- Jakie moce niewiary można stwierdzić? W jaki sposób stosunek do Boga jest fałszywy - świadomie lub nieświadomie (przez pomyłki, fałszywe wyobrażenia, przesądy, nieświadome projekcje, wątpliwości intelektualne, poczucie winy, świadome i nieświadome opieranie się Bogu, ucieczki, fałszywe zależności, tworzenie sobie bożków)?

- Jakiego rodzaju jest więc indywidualny obraz Boga i struktura wiary? W jakim stosunku stoi prawdziwa i fałszywa wiara?

- Na skutek jakiego losu rozwija się to życie wiary, w jakich warunkach losowych i jak dany człowiek kształtował przez wiarę swój los"[13, s. 46].

Na postawienie diagnozy teologicznej będą miały wpływ: przeżycia z okresu dzieciństwa i w ogóle atmosfera panująca $w$ domu rodzinnym poszkodowanego ( $w$ tym atmosfera religijna, tolerancyjna), a także stosunek do drugiego człowieka, przyrody i środowiska oraz miejsce służby strażackiej w życiu poszkodowanego i codzienne przeżycia wynikające z pełnienia tej służby. Te czynniki wpływają na późniejsze życie wiary. 
Diagnoza teologiczna pozwala duszpasterzowi przekonać się, czy zdobył on zaufanie współrozmówcy. Całemu procesowi musi przyświecać prawda, zgodnie z którą nikt nie traktuje człowieka poważniej niż Bóg. To Bóg stworzył go na swój obraz i swoje podobieństwo, jak zapewnia Pismo Święte. Właśnie w kontakcie z duszpasterzem poszkodowany może nauczyć się patrzeć na siebie z Bożego punktu widzenia. Duchowny musi pamiętać, że rozmowa duszpasterska różni się zasadniczo od rozmowy terapeutycznej. W przypadku tej pierwszej życie ludzkie widziane jest w świetle Bożym, czyli znacznie dokładniej, ostrzej. Postrzegane jest w całej rzeczywistości, a nie w jej części. Takiemu spojrzeniu ma towarzyszyć nie atmosfera lęku, niepewności i grozy, ale poczucie, że w Bogu jest pokój, że On jest Dobrym Pasterzem, który ma o człowieka staranie i przyjmuje każdego, kto chce do Niego powrócić. Mówiąc inaczej, współrozmówca, gdy nabierze pewności, że Bóg go nie odrzuci, ale przyjmie takim, jakim jest, i że przebaczy wszelkie życiowe niedociągnięcia, upadki, może zdecydować się na wyznanie grzechów, na pokutę [26, s. 225]. Oczywiście nie można nalegać i mówić poszkodowanemu, żeby wyznał swój grzech czy się wyspowiadał. Można mu pomóc inaczej. Gdy duszpasterz widzi, że dana osoba się szamota, że ma pragnienie pojednania się z Bogiem, może powiedzieć: „Mam wrażenie, że chce mi pan(i) coś powiedzieć". Wtedy współrozmówca zazwyczaj decyduje się na wyznanie win. Tak jak strażak musi dopilnować, żeby całkowicie ugasić pożar, usunąć jego ogniska zapalne, aby nie zagrażały człowiekowi, tak duszpasterz musi bardzo dokładnie omówić winę swego współrozmówcy. Nie może być żadnych niedomówień. Możliwe, że będzie to wielki szok dla poszkodowanego [17, s. 353]. Byłoby dobrze, gdyby wtedy duszpasterz pomógł mu znaleźć pozytywne cechy jego życia i zachowania, tak by poczuł się dowartościowany i pragnął je umacniać.

\section{Pomoc duszpasterska to?}

Duszpasterska pomoc to przede wszystkim rozmowa. Bardzo istotną rolę przypisuje się w niej pytaniom. Ich zadawanie jest wielką sztuką. W duszpasterstwie mamy do czynienia z czterema zasadniczymi typami pytań. Według Scharfenberga są to:

- „pytania zamknięte, na które można odpowiedzieć „tak” lub "nie" (a więc zaczynające się od słowa „czy") albo kilkoma słowami (a więc zaczynające się od słów: „kto”, "gdzie”, „który”, „ile") i które są najmniej odpowiednie, gdyż nie posuwają rozmowy naprzód i sprowadzają ją do formy przesłuchania;

- pytania sugestywne (Czy miewa pan bóle? Od kiedy pan to ma? Prawda, przecież ma pan bóle? Czy parasol nie był czarny?)

- pytania motywacyjne (typu „Dlaczego?”), które sprowadzają na drogę racjonalizowania i prawie zawsze pobudzają zachęcają do usprawiedliwiania się przez rozmówcę (jestem niewinny). Na wiele tego typu pytań nie da się odpowiedzieć, bo często prowadzą one do zastoju w rozmowie, więc duszpasterz powinien ich unikać);
- pytania otwarte, które są dłuższe i wymagają dłuższej odpowiedzi (np. „Proszę, niech pan opowie, co pana tu sprowadza?"), a ponadto odnoszą się do uprzednich spraw (echo, wyjaśnienie pośrednie, wyjaśnienie bezpośrednie, konfrontacja, powtórzenie pytania).

Pytania otwarte są głównym elementem rozmowy, pomocy duszpasterskiej. Mogą one nie raz informować ale przede wszystkim dają poszkodowanemu możliwość emocjonalnego wytchnienia i lepszego wglądu we własny problem" [13, s. 49].

Bardzo ważną rzeczą w czasie rozmowy duszpasterskiej jest zwiastowanie Słowa Bożego. Jednak osoby szukającej pomocy nie wolno bombardować wersetami biblijnymi, bo wtedy może się ona całkowicie zamknąć w sobie albo poczuć nierównym partnerem w rozmowie, albo też umocnić w swoim uporze i obronie własnych przemyśleń. Podstawową zasiewu Słowa Bożego jest odpowiednie przygotowanie gruntu we współrozmówcy. Temu służyło nawiązanie kontaktu i poznanie osobowości człowieka, czyli sformułowanie diagnozy. Duszpasterstwo zasadza się na nauce Chrystusa. Duszpasterz musi mieć na uwadze przypowieść o siewcy, w której Jezus mówi, że ziarno pada na różną glebę i że tylko to ziarno, które pada na dobrą glebę, wydaje owoc [22, s. 33]. Podobnie jest ze zwiastowaniem Słowa Bożego podczas rozmowy duszpasterskiej czy w chwili niesienia pomocy duszpasterskiej. Zdając sobie z tego sprawę, duszpasterz musi właśnie najpierw odpowiednio przygotować grunt w swoim rozmówcy. Nieraz trzeba sprawić, by poszkodowany pozbył się uprzedzeń do Słowa Bożego czy do samego Boga, a także fałszywych projekcji, urazów, zabobonów, przesądów itp. Czasem współrozmówcę trzeba najpierw uspokoić. Można w tym celu zrobić krótka przerwę w rozmowie umożliwiającą poszkodowanemu wejrzeć w siebie i może trochę przeanalizować dotychczasową wymianę myśli. Każda przerwa musi być jednak uzasadniona i wnosić coś do rozmowy. Nie może wynikać z niewiedzy. Dobrze, jeśli na zakończenie rozmowy duszpasterz zada jakieś pytanie, które będzie impulsem do dalszych indywidualnych przemyśleń, albo zalążkiem kolejnego spotkania. Można w ten sposób zasygnalizować problem, nad którym współrozmówca powinien się zastanowić. Warto, żeby duszpasterz miał też w zanadrzu pytanie, które zachęci mówiącego do refleksji, a właściwie do zajęcia odpowiedniego stanowiska, a więc do podjęcia jakiejś decyzji. To z jednej strony bardzo trudne, a z drugiej bardzo inspirujące i ciekawe dla poszkodowanego, bo zmusza go do pracy nad sobą. Podczas rozmowy duszpasterskiej można też udzielić jakiejś rady, wskazówki, np. polecić przeczytanie odpowiedniego psalmu albo innego fragmentu Słowa Bożego,[4, s. 65-72] co z pewnością pomoże poszkodowanemu w znalezieniu ciszy, spokoju na rozmowę z Bogiem, na medytację nad nieprzemijającą prawdą, jaką jest Słowo Boże. Dopiero potem można powoli finalizować rozmowę. Na jej zakończenie duszpasterz powinien zapewnić współrozmówcę, że jeszcze raz przeanalizuje jego problem i że o swoich spostrzeżeniach poinformuje go przy następnym spotkaniu. „Wynik rozmowy należy uznać za pomyślny, jeśli udało się doprowadzić naszego partnera do poznania własnej odpowiedzialności, do uznania swego problemu jako czegoś jednorazowego, co właśnie jemu zostało postawione" [13, s. 50]. 


\section{Cel pomocy duszpasterskiej}

Celem pomocy duszpasterskiej jest przede wszystkim pomoc $w$ wierze. Żaden duszpasterz nie może $w$ takim przypadku patrzeć tylko przez pryzmat konfesji. W duszpasterstwie nie można uprawiać prozelityzmu, gdyż byłoby to zupełnym zaprzeczeniem nauki Jezusa Chrystusa. Są sytuacje, w których duchowny musi schować swoją konfesję i być zwiastunem wyłącznie Słowa Bożego. Trudności ze zwiastowaniem Słowa Bożego w rozmowie duszpasterskiej czy podczas udzielania pomocy duszpasterskiej możemy napotkać wtedy, gdy mamy do czynienia z ludźmi bardzo mocno doświadczonymi przez życie, z ludźmi, którzy byli bardzo aktywnymi chrześcijanami, a z powodu swojego cierpienia być może zamknęli się na Bożą Prawdę. W takim przypadku duszpasterz nie może pozwolić sobie na wygłaszanie kazania na temat cierpienia. Powinien raczej zapewnić poszkodowanego, że rozumie jego sytuację, że rozumie głębię jego cierpienia, krzyża [5, s. 95]. Dopiero po pewnym czasie można przejść do zwiastowania Słowa Bożego. Jednakże trzeba pamiętać, by znalazło się w nim słowo pocieszenia. Najlepiej będzie, gdy duszpasterz zapewni o pocieszeniu, które płynie z Chrystusowego krzyża, z Ewangelii. Warto wtedy zacytować odpowiedni wersety, ale tak, aby nie odstraszały, tylko utwierdzały w tym, że właściwe pocieszenie jest $w$ Jezusie Chrystusie [20, s. 141]. To jest jedna strona zwiastowania Słowa Bożego. Druga jest zupełnie inna. Słowa, które cytuje albo do których nawiązuje duszpasterz, mogą być jego współrozmówcy bardzo dobrze znane i mogą w nim budzić wspomnienia pozytywne lub negatywne. Słowa są zazwyczaj przyjmowane bardzo emocjonalnie. Dla jednego poszkodowanego mają wartość, drugiemu nic nie mówią. To zmusza duszpasterza do ostrożnego szermowania Słowem Bożym. Sytuacja może być niekorzystna, wręcz niekomfortowa, jeśli duszpasterz za wszelką cenę chce nieść pomoc poszkodowanemu tylko poprzez zwiastowane Słowo Boże. To może doprowadzić do zakłócenia komunikacji. Wcześniejszy wysiłek włożony w nawiązanie kontaktu i sformułowanie diagnozy może pójść na marne. Drwiący uśmiech albo przykre milczenie współrozmówcy są dla duszpasterza sygnałem, że komunikacja jest zerwana. Wtedy trzeba na nowo, w inny sposób, próbować nawiązać kontakt z poszkodowanym. Biblijne słowa wypowiedziane przez duszpasterza mogą też spowodować coś, czego on nie zamierzał. Współrozmówca może posłużyć się nimi, aby uciec przed rozprawieniem się ze swoim bólem. Zamiast znosić swoje cierpienie i dzięki temu wzrastać w wierze i zbliżać się do Jezusa Chrystusa, rozpoczyna dyskusję na temat zacytowanego fragmentu Pisma Świętego. Jest to sytuacja wielce niekorzystna dla duszpasterza. Sytuacja jest jasna, gdy poszkodowany sam prosi o zacytowanie wersetów biblijnych czy o modlitwę. Wówczas nie ma problemu ze zwiastowaniem Ewangelii. Taka osoba może swobodnie, nawet w ostatniej chwili życia, wzrastać w wierze[12, s. 59-60].

Z powyższych rozważań wynika, że zwiastowanie jest obowiązkiem duszpasterza. Jednakże musi być ono dostosowane do potrzeby chwili, a także do konkretnego człowieka oczekującego pomocy. Duszpasterz musi wziąć po uwagę stan fizyczny i psychiczny danej osoby. Zwiastowane Słowo Boże raz może dawać radość, szczęście, natchnie nadzieją i miłością oraz zapewniać o przebaczeniu i odpuszczeniu grzechów, innym razem może smagać, oskarżać, wytykać błędy i uchybienia, a jeszcze innym razem może osuszyć łzy i przynieść pociechę strapionemu i obciążonemu sercu. To właśnie w zwierciadle Słowa Bożego poszkodowany powinien ujrzeć siebie. Wtedy może zobaczyć, że jest grzesznikiem i że jest winny cierpienia, męki i śmierci Jezusa Chrystusa. Powinien też jednak zobaczyć nieprzemijającą miłość Boga. Powinien dostrzec Tego, który przebacza każdy grzech. Tylko wówczas może powiedzieć o swojej winie [24, s. 167]. Po wyznaniu winy człowiek nie cierpi już pod całym balastem przeszłości, nie musi stale oglądać się do tyłu, ale zaczyna nowe życie i patrzy z ufnością, nadzieją w przyszłość. Trzeba jednak pamiętać, że "[u]zyskanie całkowitej pewności i jasności odnośnie czyjejś winy nie jest tu na ziemi dla żadnego człowieka możliwe. Poznanie grzechów ma po prostu swoje granice. Można dopomóc partnerowi przez to, że w całej pokorze stanie się z nim przed Bogiem. On jeden zna najlepiej każdego człowieka, może wniknąć w głąb jego serca, wydać sprawiedliwy osąd, a wreszcie ułaskawić grzesznika. Kto doznał tej łaski i wyzwolenia z dręczącej go winy, ten będzie mógł tym bardziej miłować Boga i ludzi. Umacnianie tej miłości należy do istoty duszpasterskiej pomocy poszkodowanemu. Celem naszej pomocy będzie, aby nasz partner stał się zdolnym do uporządkowania swego życia - nie według swoich życzeń czy wyobrażeń, ale od strony Bożego prawa do panowania nad nami, do kierowania jego życiem według Bożego upodobania" [3, s. 104].

Udzielając pomocy duszpasterskiej poszkodowanemu, ofiarowuje się mu pomoc $w$ wierze w Trójjedynego Boga, a także pomoc w życiu. Poszkodowany może być człowiekiem niewierzącym lub niepraktykującym chrześcijaninem, dla którego zbawcze dzieło Jezusa Chrystusa nie przedstawia wielkiej albo żadnej wartości. Taka osoba zazwyczaj widzi w swoim cierpieniu zło albo życiowego pecha. Tu właśnie wyłania się bardzo ważne zadanie dla duszpasterza. Ma on pomóc poszkodowanemu zbudować pomost łączący z Chrystusem, tak by zrozumiał, że wszystko, cokolwiek ma, jest zasługą Boga i że tego Boga potrzebuje (potrzebuje Jego daru zbawienia). Rozmówca powinien odczuwać, jak biblijny Zacheusz, potrzebę spotkania z Chrystusem.[8, s. 229], [15, s. 20-21] W tej fazie pomocy duszpasterskiej mogą pojawić się pewne problemy. W jej pierwszych fazach, czyli podczas nawiązywania kontaktu i formułowania diagnozy, duszpasterz głównie słuchał, choć oczywiście kierował rozmową, uważał, by zmierzała ona we właściwym kierunku, zadawał odpowiednie pytania. To wszystko miało swój cel, swoje znaczenie. Teraz, w czasie zwiastowania Słowa Bożego, duszpasterz głównie mówi. Jednakże nie może on bombardować poszkodowanego teologicznymi prawdami, biblijnymi wersetami czy biskupimi orzeczeniami. Cały czas musi mieć na uwadze współrozmówcę. Poprzez swoją pomoc, rozmowę ma on po prostu przypomnieć, uzmysłowić poszkodowanemu, że teraz czas mieć staranie o duszę, o zbawienie. Chodzi o wyzwalającą moc Chrystusa [16, s. 37].

\section{Głoszenie Słowa Bożego}

Może się wydawać, że zwiastowanie, głoszenie Słowa Bożego nie przysparza duszpasterzowi żadnych problemów. Jednak 
tak nie jest. Duszpasterz musi cały czas mieć na uwadze to, z kim rozmawia, to, w jakim stanie fizycznym i psychicznym jest poszkodowany. Zwiastowanie może się odbywać w różny sposób. Na przykład poprzez literaturę - lirykę czy opowiadanie (Warto tu wspomnieć opowiadania Krystyny Royówny, ks. dr. Henryka Czembora czy ks. Jana Twardowskiego, a także pozycje doby Reformacji). Zwiastowanie Ewangelii może się również odbywać poprzez muzykę, film itp. Na pewno najprostszą metodą zwiastowania jest przeczytanie fragmentu Pisma Świętego i krótkie rozważanie. Trzeba pozwolić poszkodowanemu, żeby sam dochodził do pewnych wniosków. Dobrze, jeśli duszpasterz zna jego sytuację i dobierze dla niego odpowiedni fragment Słowa Bożego. Jednakże trzeba bardzo uważać, by sztucznie nie dopasowywać tekstu do sytuacji poszkodowanego. Należy pamiętać, że żadna składowa życia ludzkiego nie jest obca Bogu i że na każdy temat można znaleźć odpowiedni fragment. Nie wolno przy tym pozwolić na to, by poszkodowany po lekturze lub wysłuchaniu fragmentu Pisma Świętego doszedł do błędnych wniosków poprzez literalną, dosłowną interpretację tekstu, bo to może doprowadzić do pogorszenia się jego stanu. Dlatego niezwykle ważną rzeczą podczas rozmowy jest wspólna modlitwa. Byłoby dobrze, gdyby poszkodowany sam zechciał zawołać do Boga [14, s. 214]. Jeśli jednak tego nie robi, nie wolno go to tego przymuszać. Wówczas modlitwę może i powinien poprowadzić duszpasterz. W modlitwie dobrze jest zasygnalizować solidarność ze swoim współrozmówcą. Duszpasterz niosący pomoc musi cały czas pamiętać, że w sprawach wiary nie chodzi o retorykę, dar przekonywania, ale o otwarcie serca na bliźniego ku chwale Boga żywego [11, s. 61-64].

Zwiastowanie podczas rozmowy duszpasterskiej nie może być zlepkiem ambonowych sloganów. Nie może być zwykłą paplaniną, zbiorem maksym itp. To musi być bardzo przemyślana wypowiedź. Można to uczynić na wzór Jezusa Chrystusa, czyli poprzez jakieś obrazy wzięte z życia, poprzez podobieństwa czy przypowieści. Jednakże zwiastowanie nie może być tylko samymi obrazami, bo wtedy można zanudzić słuchacza. Wspomniane podobieństwa nie mogą być zbyt powszednie, gdyż osoba szukająca pomocy szybko się wyłączy albo zamknie na zwiastowanie. Duszpasterz powinien używać takiego języka, który będzie dla niego naturalny i trafı do współrozmówcy. Zwiastowanie ma poruszyć serce, ma przełamywać wszelkie opory, usuwać uprzedzenia oraz otwierać serce dla i na Boga. Podczas zwiastowania lepiej powiedzieć mniej, ale tak, by słowa zapadły w serce i wydały plon. Można to uczynić, powtarzając pewne prawdy biblijne albo zapisując je na kartce, żeby poszkodowany mógł zawsze do nich powrócić. Dziś duszpasterz może też łatwo ofiarować Biblię albo Nowy Testament wraz z Psalmami. Taki prezent może pomóc poszkodowanemu znaleźć sens własnego życia i lek na duchowy niepokój. Byłoby dobrze, gdyby w Biblii na okładkach znalazły się proponowane teksty i nr strony, gdzie szukać pomocy Bożego Słowa w potrzebie np.(pomoc w cierpieniu, chorobie, modlitwa dziękczynna, pomoc w podejmowaniu decyzji, itp.). To może upewnić poszkodowanego, że zwiastowanie nie było pozbawione sensu, ale że jest prawdą zasadzającą się na Słowie Bożym, które jest podstawą wiary i tę wiarę kształtuje. Wiara musi być stale umacniana. Osoba oczekująca pomocy duszpasterskiej powinna otrzymać tę pomoc w postaci zaufania do siebie i przekonania, że Bóg stawia przed człowiekiem zadania do końca życia, i to niezależnie od tego, w jakim człowiek jest stanie. Myślę tu przede wszystkim o stanie fizycznym. Bóg stawia zadania nawet przed osobą niepełnosprawną. Dając człowiekowi zadanie, Bóg uzmysławia mu jego godność nawet przez ciężki los [18, s. 366-367]. Poruszając tę kwestię z poszkodowanym, duszpasterz może mu podarować książkę autorstwa Joni Eraksson.

Udzielając pomocy duszpasterskiej poszkodowanemu oraz jego rodzinie, można to robić przez wzmacnianie wiary dzięki trzem elementom, które Adelheid Rensch uważa za priorytetowe, a mianowicie dzięki: medytacji, nabożeństwu i modlitwie. Nie może ich zabraknąć ani podczas rozmowy duszpasterskiej, ani podczas udzielania pomocy duszpasterskiej. Zwiastowanie ma pomóc zastanowić się nad sobą, nad własnym życiem, jego sensem. To jest chrześcijańska medytacja. Przeżywanie nabożeństwa to przeżywanie społeczności z Bogiem - czy to przez lekturę Słowa Bożego, czy przez nabożną pieśń. Dzięki temu człowiek może się otworzyć na Boga i zacząć z Nim rozmawiać w modlitwie. Najważniejszą rzeczą podczas udzielania pomocy czy porady duszpasterskiej nie jest samo wyznanie grzechów. Owszem, to jest dobre, pożyteczne i potrzebne na drodze wiary, ale najważniejsze jest to, by poszkodowany poznał drogę, którą ma iść dalej. Nie chodzi o to, by duszpasterz wskazał kolejny krok, bo to uczyniłoby z poszkodowanego niewolnika. On musi sam podejmować decyzje [7, s. 69]. Zanim to jednak zrobi, duszpasterz może, a nawet powinien przedstawić mu inne możliwości wyjścia z kryzysu, a także pokazać pewne konsekwencje takich a nie innych decyzji, a nawet niebezpieczeństwa i tragedie, jakie one za sobą pociągają. Do żadnej decyzji nie wolno przymuszać. Zachęta do zaakceptowania trudnej decyzji powinna być potwierdzona tym, że duszpasterz jest gotów udzielić pomocy i że naprawdę jej udzieli. Tu ponownie przydatna może być modlitwa - oczywiście, jeżeli poszkodowany sobie tego życzy.

\section{Podsumowanie}

Należy bardzo uważać na to, by zwiastowaniem nie zrazić do siebie rozmówcy. Nie może być ono czynione na siłę. Należy też zwracać uwagę na to, żeby podczas zwiastowania, gdy duszpasterz przejmuje inicjatywę w rozmowie, nie wytworzył się dystans pomiędzy poszkodowanym a duchownym. Wówczas atmosfera stanie się przygniatająca, współrozmówca będzie miał poczucie, że jego wolność jest zagrożona, i skryje się, jak bokser, za podwójna gardą. Człowiek oczekujący pomocy duszpasterskiej nie może czuć, że traci wolność, że duszpasterz chce mu ją zabrać. Aby do tego nie doszło, duszpasterz, podsumowując rozmowę, musi się zastanawiać nad tym, jak ją zakończyć, ale także nad tym, jak zapewnić poszkodowanego, że otrzyma dalszą pomoc duszpasterską. Jeśli poszkodowany jest w szpitalu, duszpasterz może mu wspomnieć o szpitalnej kaplicy, gdzie codziennie odbywają się modlitwy. Może też skontaktować go z osobą, która pomoże mu się do tej kaplicy udać. Duszpasterz nie może rozmawiać z poszkodowanym o wszystkim i o niczym. Nie może zakładać sztywnych ram czasowych spotkania, ale musi mieć na uwadze to, z kim i gdzie rozmawia. Musi bacznie 
obserwować poszkodowanego, aby nie przekroczyć granicy jego sił, bo to oznaczałoby, że rozmowę należy zakończyć, chociaż sama diagnoza i pomoc nigdy się nie kończą. Gdy problem i sposoby jego rozwiązania zostały omówione i gdy poszkodowany wybrał drogę, którą pragnie pójść, rozmowę rzeczywiście można już zakończyć. Nie oznacza to wcale, że kontakt zostaje zerwany. Duszpasterz powinien jeszcze raz poinformować współrozmówcę o możliwości ponownego skontaktowania się i spotkania z nim. Poszkodowany musi pozostać z poczuciem, że duszpasterz wierzy w jego poprawę, w możliwość odnalezienia siebie. Spotkanie duszpasterskie dzieje się bowiem w nadziei na przyszłość, która wypełnia się w Królestwie Bożym.

Każda rozmowa czy pomoc duszpasterska zmusza duchownego do refleksji, do wejrzenia w siebie. Nie pozostaje też bez wpływu na jego psychikę i pełnioną przez niego służbę. Czasami wręcz odciska swoje piętno na jego życiu. Podczas rozmowy duszpasterz musi często identyfikować się ze swoim współrozmówcą, aby go lepiej rozumieć. Po jej zakończeniu powinien jednak radykalnie się oczyścić i „wrócić do siebie”, aby pozostać osobą zdrową psychicznie i móc dalej pomagać innym [6, s. 273-274].

\section{Literatura}

[1] Baker M., Jezus. Największy terapeuta wszech czasów. Psychologiczne przesłanie Ewangelii, Wydawnictwo Czarna Owca, Warszawa 2011.

[2] Bendyktowicz O., Duszpasterstwo i psychoterapia, Wydawnictwo Naukowe ChAT, Warszawa 2002.

[3] Benedyktowicz W., Co powinniśmy czynić. Zarys ewangelickiej etyki teologicznej, Wydawnictwo ChAT, Warszawa 1993.

[4] Bonhoeffer D., Naśladowanie, Wydawnictwo „W drodze”, Poznań 1997.

[5] Bonhoeffer D., Wybór pism, Biblioteka Więzi, Warszawa 1970.

[6] Broocks R., Bóg nie umart, Dom Wydawniczy Rafael, Kraków 2013

[7] Carlson R., Antidotum na wielki ból, Studio Emka, Warszawa 2004.

[8] Drath J., Poniewierski J. (red.), Na początku był Chrystus, Wydawnictwo Znak, Kraków 2016.

[9] Fallaci O., Siła rozumu, Wydawnictwo Cyklady, Warszawa 2004

[10] Giemza B., Hintz M. (red.), Luterański katechizm dla dorosłych, Wydawnictwo Warto, Dzięgielów 2017.
[11] Grabowski J., Przewodnik dla poszukujących, Edycja Świętego Pawła, Częstochowa 2016.

[12] Grabowski J., Przewodnik dla pytających o wiarę, Edycja Świętego Pawła, Częstochowa 2015.

[13] Gryniakow J., Duszpasterstwo ewangelickie, Wydawnictwo Naukowe ChAT, Warszawa 1980

[14] Hahn W., Zaburzenia psychiczne w świetle Biblii, Wydawnictwo Koinonia, Ustroń 2008.

[15] Halik T., Cierpliwość wobec Boga, Wydawnictwo WAM, Kraków 2013.

[16] Hintz M., Chrześcijańskie sumienie. Rozważania o etyce ewangelickiej, Wydawnictwo Głos Życia, Katowice 2006.

[17] Katolicki katechizm dla dorosłych, Wydawnictwo Świętego Wojciecha, Poznań 1987.

[18] Kübler-Ross E., Koło życia. Rozważania o życiu i umieraniu, Laurum, Warszawa 2010

[19] Lasogga F., Psychische Erste Hilfe bei Unfällen, Oldenburg 2009.

[20] Miduch M., Biografia Syna Bożego, Wydawnictwo WAM, Kraków 2017.

[21] Miller W., Practical Psychology for Pastors, Prentice-Hall, New Jersey 1985

[22] Nesti C., Mój psycholog nazywa się Jezus, Edycja Świętego Pawła, Częstochowa 2008.

[23] Rensch A., Das seelsorgerliche Gespräch, Göttingen 1970.

[24] Sauter G., Podstawowe pytania wiary, Wydawnictwo Augustana, Bielsko-Biała 1997

[25] Schroeder M., 100 pytań do kapelanów Straży Pożarnej, SA PSP Poznań, 2004.

[26] Wojciechowski M., Jak dziś mówić o wierze, Wydawnictwo Petrus, Kraków 2016

KS. ST. KPT. ADAM GLAJCAR - kapelan krajowy strażaków wyznania ewangelicko-augsburskiego. Swoją duszpasterską służbę pełnił w parafiach w Goleszowie i Wiśle Czarnem. Obecnie jest proboszczem-administratorem w Częstochowie. Założył kościelny periodyk "Nasza Gazetka”. Swoimi artykułami wzbogacił książkę 100 pytań do kapelanów straży pożarnej pod redakcją Macieja Schroedera. Był członkiem zespołu opracowującego ceremoniał pożarniczy. Jest współautorem broszur Historia ewangelickiego życia religijnego w Wiśle Czarnem i 100-lecie poświęcenia kamienia węgielnego kościoła Wniebowstąpienia Pańskiego w Częstochowie, a także autorem wielu artykułów o tematyce historyczno-religijnej, etycznej i duszpasterskiej. 